\title{
Basement controls on Acadian thrusting and fault reactivation along the southern margin of the Welsh Basin
}

\author{
D I Schofield, $J$ A Aspden, S J Kemp, $R$ J Merriman and P R Wilby \\ British Geological Survey, Keyworth, Nottingham, NG12 5GG, UK
}

Inversion of the Lower Palaeozoic Welsh Basin during the Early to Mid-Devonian is generally thought to have been achieved by a combination of approximately co-axial shortening and transcurrent movement along major faults to produce a strongly partitioned transpressional strain. However, new field observations from Rhydwilym in southwest Wales reveal superimposed deformations which indicate that thrust tectonics operated within the Welsh Borderland Fault System (WBFS) along this segment of the basin margin. An increasing regional magnetic response toward the south suggests that contrasting depth to magnetic basement across the WBFS may have buttressed basin shortening and provided the focus for thrusting and lateCaledonian or proto- Variscan reactivation.

KEY WORDS Welsh Borderland Fault System; basin inversion; fault reactivation; Acadian Orogeny

\section{INTRODUCTION}

The Fishguard district of southwest Wales is predominantly underlain by basinal mudstones with subordinate sandstone-dominated units, and mafic and felsic volcanosedimentary and intrusive igneous rocks, including the Fishguard Volcanic Group. The succession ranges in age from Cambrian through to Late Ordovician (Ashgill) and is disposed around a series of arcuate, first order, Acadian macrofolds, which trend WSW-ENE (Fig. 1). This overall architecture is disrupted by a complex system of strike faults which form part of an array of structures that preserve a history of Ashgill and Telychian movement as well as Acadian reactivation (Davies et al. 1997). The south of the Fishguard district is transected by the W-trending CwmCynnen Fault (CWF) which represents the westernmost extension of the WBFS (Fig. 1) and incorporates the amalgamated Pontesford and Tywi Lineaments of Central Wales (Schofield et al. in press; Wilby et al. 2007).

Conventional models for inversion and tectonic thickening of the Lower Palaeozoic Welsh Basin, attributed to the Early to Mid-Devonian Acadian Orogeny, envisage strongly partitioned transpressional strain during either late-Caledonian oblique terminal collision between the palaeocontinents of Avalonia and Laurentia (e.g. Woodcock et al., 1988), or proto-Variscan contraction of the Rheic Ocean to the south of Avalonia (Woodcock et al. 2007). Throughout much of the southern Welsh Basin, in the presently exposed upper crustal level, this was largely achieved by a combination of heterogeneous pure shear, leading to more-or-less coaxial NW-SEdirected shortening and partitioned simple shear, resulting in transcurrent movements along major strike faults. These are typically evidenced by the close relationship between a single generation of gently NE-SW-plunging open folds that are developed on a regional through to outcrop scale, and by a single, more-or-less axial-planar slaty cleavage and steep, NE-SW-trending strike parallel fault systems (Fig. 1). A component of more homogeneous transpression is locally indicated by small angles of 
cleavage transection with respect to fold axes (Woodcock et al. 1988). Known exceptions to this simple deformation history are preserved around the Harlech Dome and Arfon Basin of the northern Welsh Basin, where early cleavages, fold structures and isotopic resetting attest to both complex basement controls on fold and cleavage patterns as well as local preservation of a pre-Acadian, Early Ordovician deformation episode (Roberts 1967; Lynas 1970; Howells \& Smith 1997; Schofield et al. 2008).

Structural elements in the southwestern part of the basin pass through a broad flexure, from NE-SW trending to E-W trending, where the main Variscan fold belt to the south impinges upon them (Fig. 1). Accompanying this flexure is a change in structural style that forms the subject of this paper.

Recent field surveying by the BGS in the Fishguard district has revealed a ca. $3 \mathrm{~km}$ wide, fault-bounded belt of mudstone which preserves gently inclined to flatlying, pervasive first phase tectonic fabrics that are generally oriented at low angles to bedding. These fabrics contrast markedly with similar, but more steeply oriented, cleavages observed elsewhere in the Welsh Basin and provide new insights into Acadian deformation mechanisms. The gently inclined tectonic layering is overprinted by a subsequent generation of folding, thrusting and cleavage development. These fabrics are considered in the context of both Acadian tectonics and the main phase of Variscan deformation which is widely expressed further to the south of the study area (e.g. Hancock et al. 1983).

The sections described herein are located on the basinward margin of the Welsh Borderland Fault System (WBFS, Fig. 1), where dramatic changes in thickness of the Lower Palaeozoic cover sequence, coincident with pronounced regional magnetic gradient, geophysical lineaments and a plexus of strike faults, mark the location of the proposed boundary between two fundamental Neoproterozoic basement blocks, the Cymru Terrane to the west and the Wrekin Terrane (also known as the West Midlands Microcraton) to the east (Fig. 1; Pharaoh \& Carney 2000). The location of these structures is used to inform discussion about the possible control of basement architecture on Acadian deformation and the importance of fault reactivation during later movements.

For the purpose of this study, type sections for the deformation style have been recognised around the village of Rhydwilym on the Carmarthenshire-Pembrokeshire border (Fig. 1) which are considered a well exposed representative of the local structural style, particularly those at Troedyrhiw Farm where a near continuous, ca. $135 \mathrm{~m}$ long, cross-strike section is exposed adjacent to the alluvial tract of the Eastern Cleddau river and its tributary (Fig. 2). In order to establish the tectonic context of these fabrics a detailed examination of the field relationships was combined with a mineralogical and petrographic study of the microstructures.

\section{GEOLOGICAL DESCRIPTION}

The Troedyrhiw Farm section at Rhydwilym (SN 11332536 to 1137 2522) comprises thinly laminated mudstones of the Ordovician (Llanvirn) Penmaen Dewi Formation and preserves two distinctive phases of deformation (local D1 and D2), illustrated in Figure 2. Although bedding (S0) is often difficult to distinguish, rare, 0.5 to $1.0 \mathrm{~cm}$ beds of laminated, fine-grained sandstone were locally observed parallel, or slightly oblique, to the main (S1) pervasive slaty cleavage (Fig. 3a).

The overall geometry of the outcrop is defined largely by the second deformation (D2). This episode has generated a set of folds (F2), thrust faults and planar fabrics (S2) that deform earlier structures (S1/F1). At outcrop scale the F2 mesofolds comprise open (interlimb angles typically $\geq 50^{\circ}$ ), approximately 
cylindrical, very gently plunging $\left(<10^{\circ}\right)$ structures. They have upright to steeply Ndipping, W-E trending axial planes and verge weakly toward the south (Fig. 3b). These folds have ca. $20 \mathrm{~m}$ wavelengths and preserve minor parasitic folds which verge toward (outcrop-scale) antiforms. Crenulation cleavage microfolds are locally developed on S0/S1 surfaces, producing a marked L2 crenulation lineation. S2 comprises a spaced set of fractures, crenulation planes and kink bands that are dominantly moderately to steeply inclined toward the north, or form conjugate or arcuate radial sets that appear to have accommodated shortening and interstratal shearing during folding (Fig. 3c, d). Faults also occur on a variety of scales and are largely associated with progressive non-coaxial shortening (Fig. 3b). The largest observed structures form a series of gently to moderately $\mathrm{N}$-inclined fracture surfaces marked by disruption of S0/S1 and by the widespread intrusion of quartz veins (V2, Fig 3e) which locally cross-cut S1. A variety of asymmetric structures, including shear bands and en-echelon arrays of veins, indicate that these have a south-directed thrust sense of displacement (Fig. 3f). Smaller-scale faults generally form arcuate, moderately $\mathrm{N}$-inclined surfaces that nucleate in small scale antiformal hinges, or parallel to S0/S1 surfaces, and generally accommodate small-scale overthrusting of Svergent antiforms. V2 also occurs as lenses developed in fold hinge zones accommodating a component of vertical extension and as veinlets locally intruding minor fractures.

Overall, the pattern of strain associated with the younger (D2) phase of deformation is consistent with N-S directed horizontal contraction, accommodated by both coaxial shortening and non-coaxial, S-directed, thrusting. D2 is interpreted to record progressive shortening with formation of $\mathrm{S} 2$ cleavages followed by vertical extension and the intrusions of quartz veins, followed in turn by movement of F2 thrusts which locally displace both S2 and V2.

Everywhere, this tectonic episode deforms an earlier composite fabric comprising bedding (S0) and a slaty cleavage (S1). The style of F2 mesofolds indicates that their enveloping surface was flat-lying or gently inclined toward the north. This suggests that, in contrast with cleavage throughout much of the lower Palaeozoic Welsh Basin, S1 in the Rhydwilym area was also flat-lying or gently Ndipping prior to subsequent (D2) shortening. Where observed, S0 is typically parallel to S1. However, at the southern end of the outcrop a single, tight (interlimb angle ca $35^{\circ}$ ) fold hinge can be observed in bedding. This structure has a gently N-dipping axial surface, and gently E-plunging azimuth and is asymmetrical with one limb parallel to cleavage and the other acutely cross-cut by cleavage (Fig. 3a). Assuming that the long limb of this fold pair is the S0/S1 parallel limb, this structure is north vergent. However, it is probably unwise to draw conclusions about regional D1 vergence from such limited data as it is not possible to verify the sense of vergence from this section where only one fold hinge is preserved, and such folds have not been observed elsewhere.

The pattern of strain associated with the earlier deformation (D1) argues for a steeply oriented component of minimum extension, such as that which develops during body translation with simple shear in a thrust hanging wall either by bedding parallel simple shear or by layer shortening (e.g. Ramsay \& Huber 1987). At the Troedyrhiw locality, both processes may operate together, the former indicated by the strong bedding parallel tectonic fabric (S1) with the latter supported by local development of asymmetric fold structures. 
A limited petrographic study was carried out to establish whether S0, S1 and S2 could be distinguished more clearly throughout the main body of the mudstone. A single sample of cleaved mudstone (BGS mineralogy and petrology laboratory number, MPLL754) was prepared and analysed by X-ray diffraction (XRD) using the standard technique recommended by Kisch (1991), in order to determine the Kubler Index (KI, $\Delta^{\mathrm{o}} 2 \theta$ ) of white mica (illite) crystallinity. This analysis indicates that the sample has a KI of 0.41 , indicating that it has just reached the low anchizone grade of low-grade metamorphism (Merriman \& Peacor 1999). This grade is characteristic of large tracts of the southern Welsh Basin, including the Fishguard area (cf. Fig 5, Merriman 2006), and is thought to be largely the result of recrystallisation during sedimentary burial during subsidence in the Welsh Basin (Robinson \& Bevins 1986).

In addition, two polished thin sections, one parallel (YZ section with respect to D2 strain axes) and one normal to the intersection lineation of S2 on S1 (XZ section), were prepared for backscattered scanning electron microscopy (BSEM). BSEM analysis shows that the mudstone consists of clastic quartz and chlorite-mica grains, in the fine-sand to silt size range, set in a clay matrix that largely consists of white mica and chlorite (Fig. 4a). Detrital grains of Fe-oxide (Fig. 4b), apatite and monazite are scattered through the matrix.

In accordance with the field observations, three microfabrics can be distinguished petrographically. Firstly, a crude sedimentary lamination (S0) is indicated by the subparallel alignment of the crystallographic 001 stacking planes within the chlorite-mica grains (Fig. 4c). These stacks were formed by sedimentary burial of weathered mafic volcanic detritus, including biotite and other ferromagnesian minerals, and the internal stacking planes developed approximately parallel to bedding during static deep diagenesis. The chlorite-mica grains illustrated here (Fig. 4c) are oriented at a high angle to the pervasive slaty cleavage (S1). This suggests local crenulation or folding of $\mathrm{S} 0$ in the mudstones that is cryptic at outcrop scale, or otherwise rotation of bedding surfaces with respect to cleavage.

The second and most obvious petrographic microfabric is a slaty cleavage (S1). It is clearly seen as a series of spaced cracks, up to ten microns wide (Figs. 4a, c), some of which have probably been accentuated by thin section production. However, within the domains bounded by these fractures, many laths and flakes of white mica and chlorite (1 - $20 \mu \mathrm{m}$ long) are elongated in the S1 microfabric (Fig. 4ce). Some of the smaller grains may have developed their alignment by diffusive mass transfer, whereas the larger grains appear to have been rotated in the slaty cleavage. Rotation, kinking, and fracturing in the S1 microfabric has deformed many of the chlorite-mica stacks, and these show stacking planes oblique to S0 (Figs. 4a, c, e). Dilation of the stacking planes during deformation has also allowed syn-kinematic white mica to be generated within the stacks by diffusive mass transfer from the mudstone matrix (Fig. 4f).

A third microfabric (S2) consists of a series of discontinuous fractures, up to ca $0.35 \mathrm{~mm}$ thick that cut both S0 and S1. The veins are typically filled with Fe-oxide, and a narrow halo of $\mathrm{Fe} / \mathrm{Mg}$-chlorite is commonly developed in the adjacent mudstone (Fig. 4g). The Fe-oxide vein-fills sometimes show a preferred orientation with long axes normal to the veins' walls, whereas chlorite developed in the halos may show a crude parallelism with the local trend of the vein, but more commonly remains orientated in the S1 fabric (Figs. 4g, h). Thus S2 appears to have acted as conduits for fluids that carried dissolved Fe, and formed as kink bands during shortening. These fluids were hot enough to precipitate Fe-oxide within the veins and generate $\mathrm{Fe} / \mathrm{Mg}$ - 
chlorite adjacent to the veins, suggesting temperatures of at least $150^{\circ} \mathrm{C}$ (e.g. Alt 1999).

In summary, mineralogical and petrographical analyses show that peak metamorphic conditions of low anchizonal grade were achieved, similar to those attained throughout much of the southern Welsh Basin. Furthermore, three microfabrics are present, consistent with field observations that illustrate two deformation phases (D1/D2) superimposed on the original bedding fabric (S0).

\section{SUPERPOSED THRUSTING EPISODES}

The Rhydwilym sections provide evidence of there having been two tectonic episodes in this district. Both these events were formed by horizontal crustal shortening, locally accommodated by thrusting. Although the overall character of strain observed around Rhydwilym contrasts markedly with that elsewhere in the basin, the metamorphic grade and style of the S1 microfabric is consistent with that formed during the main phase of Acadian deformation throughout the rest of the basin. The weaker, lower grade, overprinting F2 and S2 are kinematically similar to D1 (see below) and may represent the effects of progressive Acadian shortening, or they may have been formed by reactivation during the main phase of Variscan tectonics during the Late Carboniferous. In the latter case, the south-directed sense of displacement indicated by D2 at the Rhydwilym locality contrasts with the main Variscan transport direction elsewhere where northward translation of Upper Palaeozoic strata was rooted in a décollement horizon coincident with the Johnston Thrust (Dunne 1983) and probably reflects backthrusting deep within the orogenic foreland (Holder \& Leveridge 1994), most likely controlled by the orientation of the pre-existing structure.

While the observed present-day upper crust throughout much of the Welsh Basin is dominated by structures formed by coaxial shortening, Coward \& Siddans (1979) proposed that lithospheric scale deformation, by necessity, involved a detachment-dominated process. This model was based on observations from the Acadian tectonic record of North Wales where they identified a contrast between a high degree of observable crustal shortening and apparent low degrees of thickening. This led them to conclude that this was likely achieved by imbrication along an unexposed, deeper crustal décollement structure.

Although the strain analysis method used by Coward \& Siddans is now considered suspect (Nakamura \& Borradaile 2001), some subsequent studies in North Wales have validated this model by recognising that folding in competent horizons has been accommodated along recognised low angled décollement surfaces (e.g. Pratt 1991). However, until the present study, the lack of recognised thrust faults and inverse stratigraphic stacking propagated at surface, particularly in the southern part of the basin, and the paucity of deep-crustal seismic constraint, has made linking hypothetical models of lower and mid crustal shortening to observed upper crustal deformation by thrust tectonics hard to constrain.

Localised small scale thrust displacements have, however, been observed in some parts of the basin, particularly in its southernmost extension. Earlier workers in the Fishguard area noted the presence of thrust faults on the steep, or overturned, limbs of S-verging folds (Thomas \& Cox 1924; Evans 1945). Elsewhere in the basin, this style of structure has more recently been interpreted to reflect the influence of local rheology; typically imbricating multilayered sequences of thinly interbedded turbidite mudstone and sandstone along steep limbs of parasitic, low order folds (Davies et al. 1997). 
Evidence from the Rhydwilym area indicates a more penetrative style of thrust-tectonics. In this area we envisage fabric formation to be the result of strongly non-coaxial deformation that could have operated across a broad spectrum of tectonic scenarios. At one end of this spectrum, early, post-diagenetic shortening of the mudstone pile could have been accommodated by intra-basinal thrusting, forming a series of flat belts, such as that described herein, and ramps exploiting pre-existing, flat-lying anisotropies. At the other end of the spectrum, the flat-lying fabrics in this region could reflect thin-skinned thrusting as a local deformation regime in an otherwise thick-skinned, Acadian deformation episode (e.g. Woodcock \& Soper, 2006).

\section{BASEMENT CONTROLS ON DEFORMATION}

The recent BGS survey indicates that Acadian thrusting was restricted to the basinward edge of the WBFS in the Fishguard district, while elsewhere in the basin, shortening appears to have been largely coaxial (e.g. Davies et al. 1997). The WBFS itself preserves a long history of reactivation, with a pre-Acadian history dominated by episodes of Ashgill and Telychian movement (Woodcock \& Gibbons 1988; Davies et al. 1997; Schofield et al. 2004; Barclay et al. 2005). These are indicated by repeated changes in thickness of strata across the various fault components and by the development of a series of unconformities that are related to both eustatic processes and localised footwall uplift.

The significance of the WBFS is also illustrated by marked regional geophysical gradients coincident with the fault zone (Fig. 5). For instance, the Cymru Terrane (to the north of the WBFS) is generally more weakly magnetic than the Wrekin Terrane (to the south) and the WBFS has thus been interpreted as the position of a through-crustal anisotropy juxtaposing terranes of contrasting composition (Carruthers et al. 1992). Within the study area, the presence of a substantial WSWtrending high located to the south of the WBFS, known as the 'Haverfordwest High' (Fig. 5; Norton et al. 2000), has been interpreted both in terms of contrasting crystalline basement compositions and of a dramatic change in the thickness of their respective cover successions (Brooks et al. 1983; Carruthers et al. 1992; Norton et al. 2000).

Given the strong localisation of thrusting, we envisage that contrasting basement/cover relationships across the WBFS were key in controlling the style of deformation in this area. In particular, that the varying thickness of compressible sediments overlying the rigid, crystalline basement across the WBFS gave rise to a strain incompatibility during the main Acadian basin inversion and, that locally, this produced different deformation styles across the fault zone. The thicker succession to the north of the WBFS has taken up Acadian compression largely through coaxial shortening, as seen elsewhere in the basin, while in the Rhydwilym area, where the WBFS has a W to E trend, the thin sedimentary succession located on the outboard margin of the Wrekin Terrane underwent non-coaxial, thrust-dominated deformation. The latter may have been rooted in a steep reverse fault reactivating the basement contact zone during inversion, which probably facilitated southward translation of the basinal succession across the foreland of the Wrekin Terrane in this part of the southern Welsh Basin (Fig. 6).

This style of deformation buttressing has been observed elsewhere in the Welsh Basin as a local phenomenon, particularly where strain partitioning has occurred around exposed rigid objects (Tan y Grisiau microgranite of Snowdonia (Campbell et al. 1985); Coedana Complex of Anglesey, (Shackleton, 1954)) or 
concealed, geophysically anomalous, basement features (Berwyn Hills, North Wales (Awan \& Woodcock 1993)). However, most significantly, Cope (1979) described a similar style of deformation from sections around Llangynog, in Carmarthenshire, to the southeast of Rhydwilym within the WBFS. Here, south facing folds with inverted southern limbs are associated with thrusting within Late Neoproterozoic and Lower Palaeozoic rocks and apparent strong partitioning between Caledonian (Acadian) and Variscan structures. Cope (1979) interpreted these to be strongly controlled by a geophysically constrained basement high which in the context of the present study, provides some evidence for the extent of this structural style within this segment of the WBFS.

Deformation in the NE-trending, orogen-parallel part of the WBFS is thought to preserve a significant component of transcurrent displacement (Woodcock et al. 1988), while pervasive Acadian thrust tectonics (D1), recognised by this study, appear to be localised in the W-trending segment of the WBFS in SW Wales, oblique to the main orogenic trend. We propose that both thrusting and strike slip comprised elements of a transpressional system in which the main bounding transcurrent fault is defined by the NE segment of the WBFS reactivating a fundamental basement structure (Fig 6), and that subsequent weak deformation (D2) may have resulted from progressive Acadian thrust tectonics or further reactivation along this structure during the Variscan.

\section{ACKNOWLEDGEMENTS}

The authors would like to thank Graham Leslie and Chris Thomas for providing constructive comments on an earlier version of this manuscript. D I Schofield, J A Aspden, S J Kemp, R J Merriman and P R Wilby publish with the permission of the Executive Director, British Geological Survey (NERC).

\section{REFERENCES}

Alt JC. 1999. Very low-grade hydrothermal metamorphism of basic igneous rocks. 16669-201 In Low-grade Metamorphism, Frey M, Robinson D (eds). Blackwell Science.

Awan MA \& Woodcock NH. 1993. Structural arcuation in the Berwyn Hills, North Wales. Geological Journal, 28, 179-189.

Barclay, WJ, Davies, JR, Humpage, AJ, Waters, RA, Wilby, PR, Williams, M, Wilson D. 2005. Geology of the Brecon district - a brief explanation of the geological map. Sheet explanation of the British Geological Survey. 1:50 000 Sheet 213 Brecon (England and Wales). Keyworth, Nottingham: British Geological Survey, 38pp. British Geological Survey. 2007. Magnetic Anomaly UK South. 1:625 000. Keyworth, Nottingham: British Geological Survey.

Brooks M, Mechie J, Llewelyn D J. 1983. Geophysical Investigations in the Variscides of Southwest Britain. In The Variscan Fold Belt in the British Isles, Hancock PL (ed). Adam Hilger Bristol, 186-197.

Campbell SDG, Reedman AJ \& Howells MF. 1985. Regional variations in cleavage and fold development in North Wales. Geological Journal, 20, 43-52.

Carruthers RM, Fletcher CJN, McDonald AJW, Bevins RB. 1992. Some constraints on the form of the Welsh Basin from regional gravity and aeromagnetic data, with particular reference to Central Wales. Geological Magazine, 129, 515-522. Cope JCW. 1979. Early history of the southern margin of the Tywi Anticline in the Carmarthen area, South Wales. In The Caledonides of the British Isles - reviewed, 
Harris AL, Holland CH, Leake BE (eds). Geological Society, London, Special Publication 8, 527-532.

Coward MP, Siddens AWB. 1979. The tectonic evolution of the Welsh Caledonides. In The Caledonides of the British Isles - reviewed, Harris AL, Holland CH, Leake BE (eds). Geological Society, London, Special Publication 8, 187-198.

Davies JR, Fletcher CJN, Waters RA, Wilson D, Woodhall DG, Zalasiewicz JA. 1997. Geology of the country around Llanilar and Rhayader. Memoir of the British Geological Survey, Sheets 178 and 179 (England and Wales).

Dunne WM. 1983. Tectonic evolution of SW Wales during the Upper Palaeozoic. Journal of the Geological Society, London, 140, 257-266.

Evans WD. 1945. The geology of the Prescelly Hills, north Pembrokeshire. Quarterly Journal of the Geological Society of London, 101, 89-110.

Hancock PL, Dunne WM, Tringham ME. 1983. Variscan deformation in southwest Wales. In The Variscan Fold Belt in the British Isles, Hancock PL (ed). Adam Hilger Bristol, 47-73.

Howells MF, Smith M. 1997. The geology of the country around Snowdon. Memoir of the British Geological Survey, Sheet 119 (England and Wales).

Holder MT, Leveridge BE. 1994. A framework for the European Variscides. British Geological Survey, Technical Report WA/94/24.

Kisch HJ. 1991. Illite crystallinity: recommendations on sample preparation, X-ray diffraction settings and interlaboratory standards. Journal of Metamorphic Geology, 9, 665-670.

Lynas BDT. 1970. Clarification of the polyphase deformation of North Wales Palaeozoic rocks. Geological Magazine, 107, 505-510.

Merriman RJ. 2006. Clay mineral assemblages in British Lower Palaeozoic mudrocks. Clay Minerals, 41, 473-512.

Merriman RJ, Peacor DR. 1999. Very low-grade metapelites: mineralogy, microfabrics and measuring reaction progress. 10-60 In Low-grade Metamorphism. Frey M, Robinson D (eds). Blackwell Science.

Nakamura N \& Borradaile G. 2001. Do reduction spots predate finite strain? A magnetic diagnosis of Cambrian slates in North Wales. Tectonophysics, 340, 133-139. Norton GE, Cooper DC, Cornwell JD. 2000. Evidence for gold mineralisation in the Lower Palaeozoic and Precambrian rocks of south-west Wales. BGS Research Report RR/00/10.

Pharaoh TC, Carney, JN. 2000. Introduction to the Precambrian rocks of England and Wales. 3-17 In Precambrian Rocks of England and Wales. Geological Conservation Review Series No. 20. Joint Nature Conservation Committee, Peterborough.

Pratt WT. 1991. The Nod Glas décollement of the Welsh Basin. Geological Magazine, 128, 279-282.

Ramsay JG, Huber MI. 1987. The techniques of modern structural geology. Vol. 2 Folds and Fractures. London: Academic Press, 700pp.

Roberts B. 1967. Succession and structure in the Llwyd Mawr Syncline, Caernarvonshire, North Wales. Geological Journal, 5, 369-390.

Robinson D, Bevins RE. 1986. Incipient metamorphism in the Lower Palaeozoic marginal basin of Wales. Journal of Metamorphic Geology, 4, 101-113.

Schofield DI, Davies JR, Waters RA, Wilby PR, Williams M, Wilson D. 2004. Geology of the Builth Wells district - a brief explanation of the geological map. Sheet explanation of the British Geological Survey. 1:50 000 Sheet 196 Builth Wells (England and Wales). Keyworth, Nottingham: British Geological Survey, 34pp. 

explanation of the geological map. Sheet explanation of the British Geological Survey. 1:50 000 Sheet 212 Llandovery (England and Wales). Keyworth, Nottingham: British Geological Survey.

Schofield DI, Evans JA, Millar IL, Wilby PR, Aspden JA. 2008. New U-Pb and $\mathrm{Rb}$-Sr constraints on pre-Acadian tectonism in North Wales. Journal of the Geological Society, London, 165, 891-984.

Shackleton RM. 1954. The structure and evolution of North Wales. Liverpool and Manchester Geological Journal, 1, 261-297.

Thomas HH, Cox AH. 1924. The Volcanic Series of Trefgarn, Roch, and Ambleston (Pembrokeshire). Quarterly Journal of the Geological Society of London, 80, 520548.

Wilby PR, Schofield DI, Aspden JA, Burt CE, Davies JR, Hall M, Jones NS, Venus J, Wilson D. 2007. Geology of the Newcastle Emlyn district - a brief explanation of the geological map. Sheet explanation of the British Geological Survey. 1:50 000 Sheet 211 Newcastle Emlyn (England and Wales).

Woodcock NH, Gibbons W. 1988. Is the Welsh Borderland Fault System a terrane boundary? Journal of the Geological Society, London,145, 915-923.

Woodcock NH, Soper NJ. 2006. The Acadian Orogeny: the mid-Devonian phase that formed the slate belts in England and Wales. In The geology of England and Wales Brenchley PJ, Rawson PF (eds). Geological Society of London, 131-146. Woodcock NH, Awan MA, Johnson TE, Mackie AH, Smith RDA. 1988. Acadian tectonics of Wales during Avalonia/Laurentia convergence. Tectonics, 3, 483-495. Woodcock NH, Soper NJ, Strachan RA. 2007. A Rheic cause for the Acadian deformation in Europe. Journal of the Geological Society, London, 164, 1023-1036.

Fig. 1 a) Regional Acadian and Variscan structural features of south Wales. CWF Cwm Cynnen Fault; CCD -Careg Cennen Disturbance; b) Location of structural traverse (A-D of Fig. 3) near Troedyrhiw Farm.

Fig. 2 Structural traverse of the Troedyrhiw Farm section at Rhydwilym [SN 1133 2536] to [1137 2522]. Positions of field photographs (Fig. 3) indicated. Stipple indicates quartz veining.

Fig. 3 Field photographs from the Rhydwilym section, all with north to the left, illustrating: a) bedding-cleavage relationship (S0/S1); b) F2 antiform folding composite S0/S1 fabric, with steep limb disrupted by N-dipping thrust plane; c) Steeply inclined S2 cleavage; d) D2 accommodation structures; e) imbricate quartz veins (V2) within a D2 thrust zone; f) asymmetric imbricate zone illustrating Sdirected displacement. Location of photographs with respect to the main section illustrated in Figure 2.

Fig. 4 Backscattered scanning electron micrographs: a. General view of the mudstone which consists of clastic, fine sand- to silt-sized quartz and chlorite-mica (chl-mi) grains in a clay matrix of white mica and chlorite. The near-vertical cracks are indicative of the slaty cleavage (S1), and in some cases these are probably artefacts of thin section production; $b$. Grains of Fe-oxide (Fe-ox) with corroded cores, apatite and monazite (all shown bright) are scattered through the matrix and are 
often associated with late, Fe-oxide veining; c. Low magnification view to show a crude sedimentary lamination (S0) indicated by the subparallel alignment of the crystallographic 001 stacking planes within the chlorite-mica grains. The near-vertical series of spaced fractures, a few microns wide, clearly illustrate the slaty cleavage (S1); d. High magnification view illustrating the development of white mica and chlorite laths and flakes within the domains bounded by the slaty cleavage; e. Typical chlorite-mica grain (chl-mi, centre) showing partial rotation of stacking planes to the near-vertical cleavage direction; f. Deformed chlorite-mica stack composed of Kwhite mica (dark layers) and Mg-rich chlorite (brighter layers). Note how the stacking planes have been deformed, kinked and fractured after rotation during cleavage formation; g. Discontinuous Fe-oxide (Fe-ox) vein showing the development of a narrow halo of $\mathrm{Fe} / \mathrm{Mg}$-chlorite in the adjacent mudstone, oriented in the S1 fabric; h. Fe-oxide vein (bright) cross-cutting the near-vertical cleavage. Note the extensive development of $\mathrm{Mg} / \mathrm{Fe}$-chlorite (chl) around the Fe-oxide vein. The small bright rounded grains are Ti-oxides (rutile/anatase) and Fe-oxide.

Fig. 5 Map of SW Wales illustrating the location of the WBFS with respect to regional magnetic gradients. Magnetic contours have a 100 nanotesla interval and are based on data from several sources, synthesised in British Geological Survey (2007). CWF -Cwm Cynnen Fault; CCD -Careg Cennen Disturbance; WBFS -Welsh Borderland Fault System.

Fig. 6 Conceptual block diagram illustrating the proposed relationship between basement architecture and Acadian structural development. 

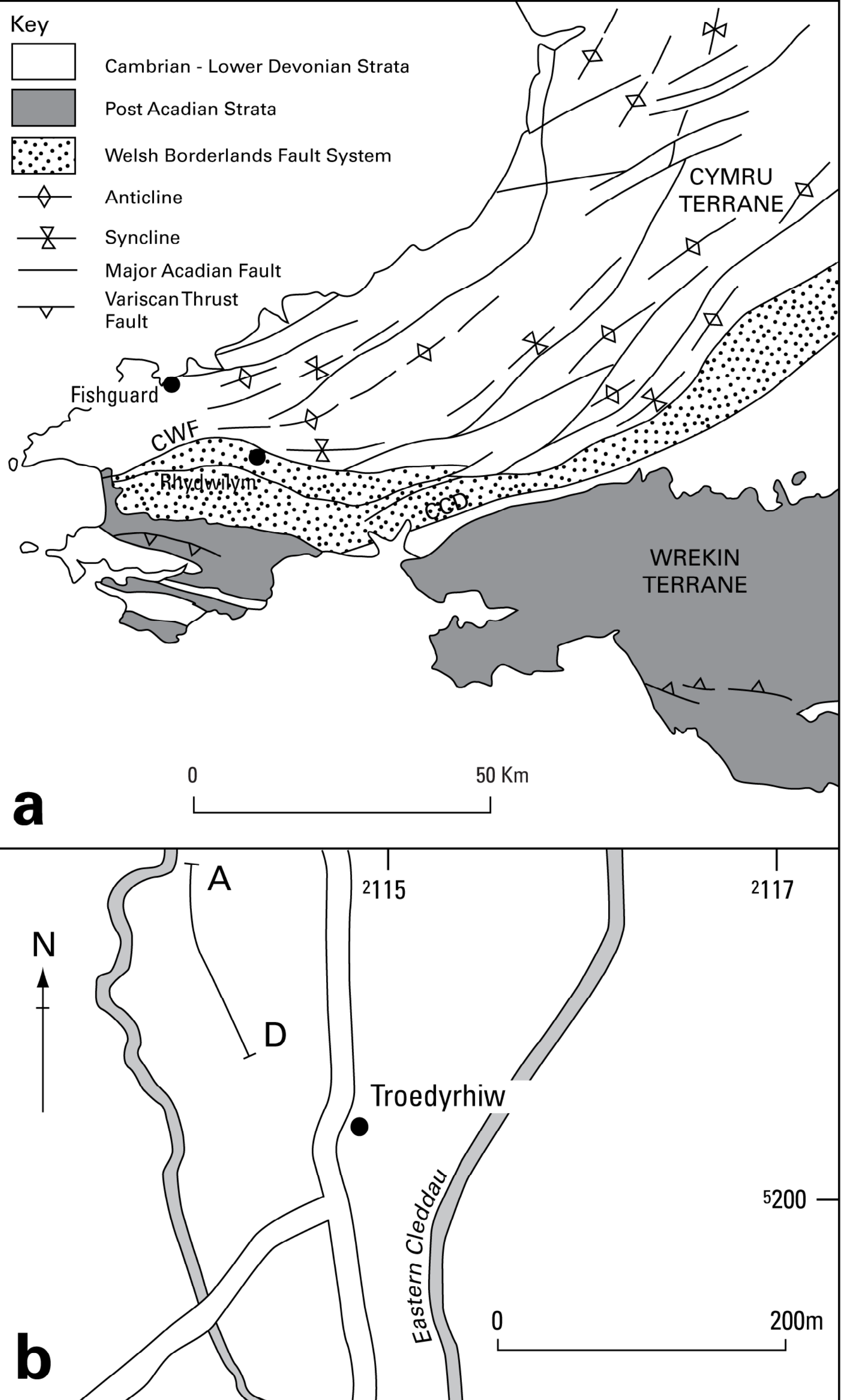

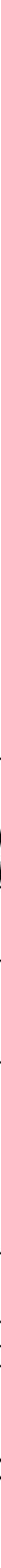

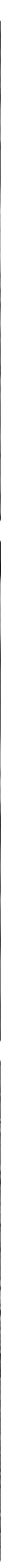

9
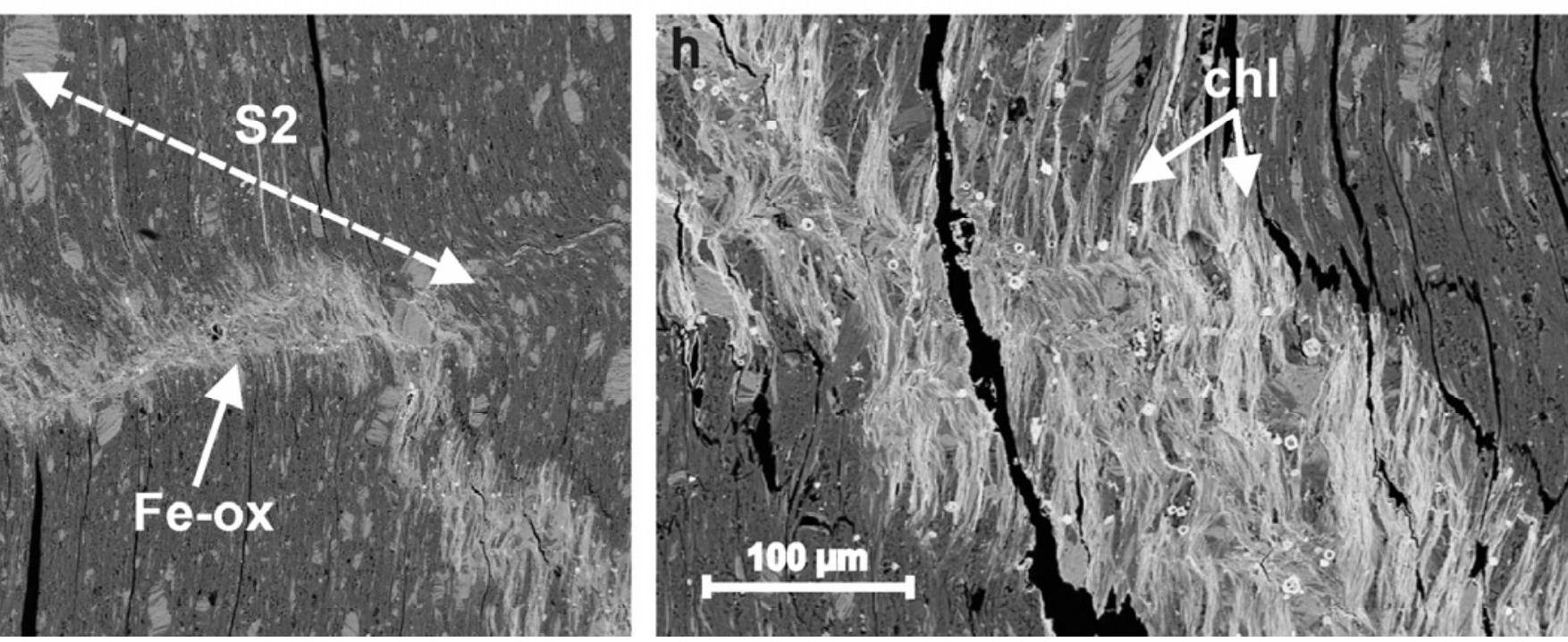


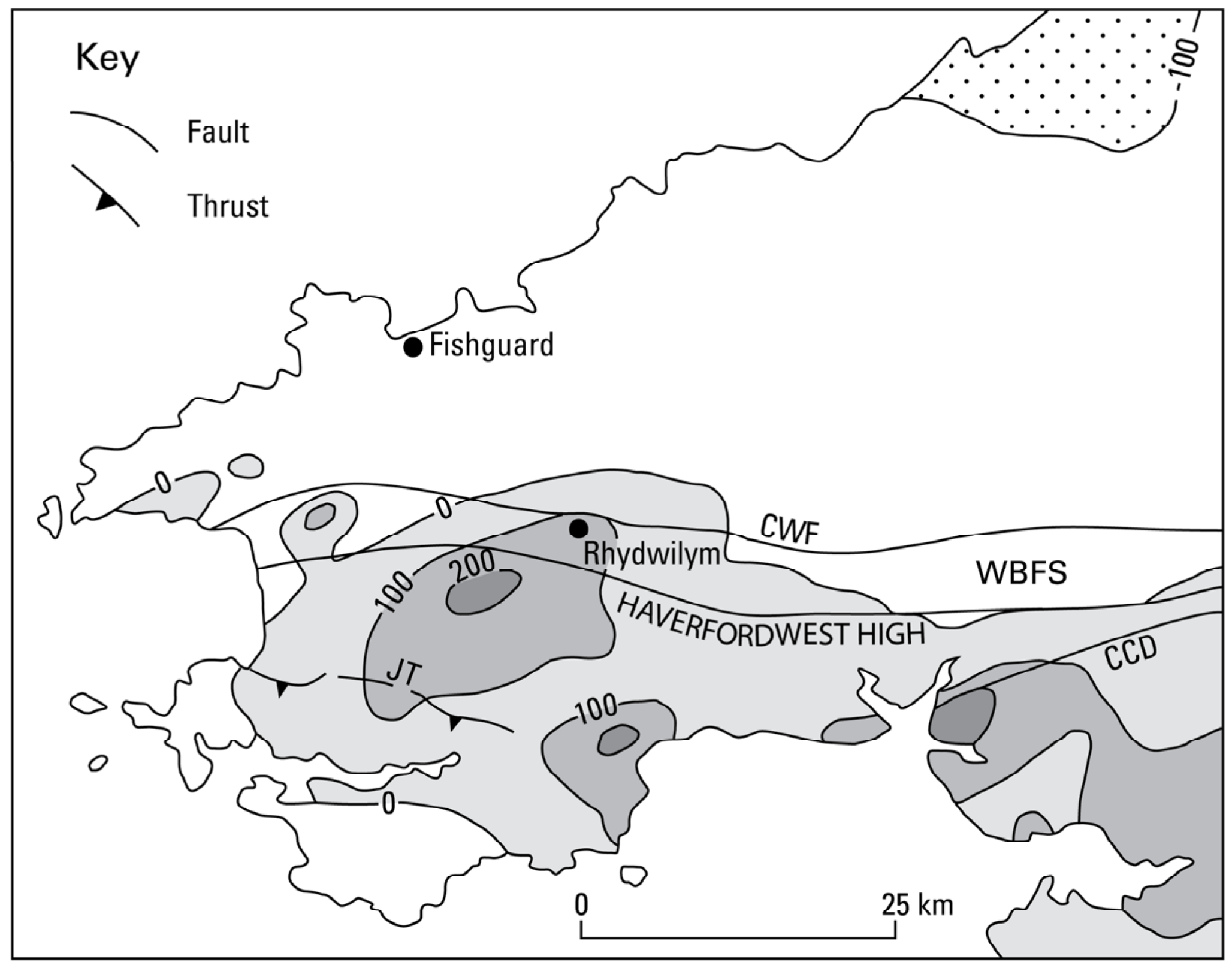




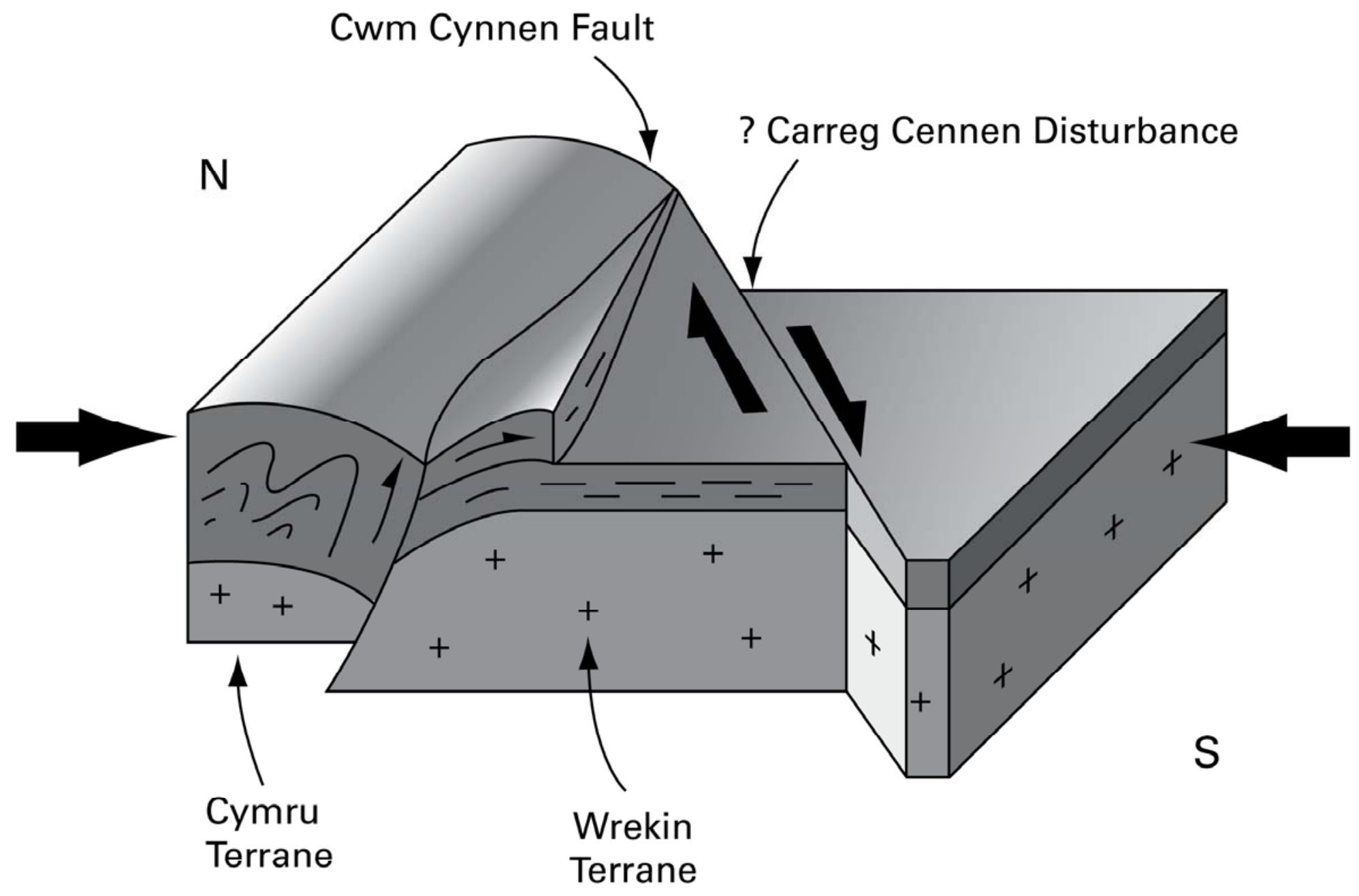

